\title{
ANAESTHETIC MANAGEMENT FOR REPAIR OF CLEFT LIPS AND CLEFT PALATES
}

J. S. WHALEN, M.D., F.A.A.P., AND A. W. CONN, |M.D., B.SC.(MED), F.R.C.P.(C), F.A.C.A. ${ }^{*}$

The anaesthetic management of cleft lip and cleft palate surgery presents many problems. This paper reviews the following aspects of these cases:

1. Associated congenital malformations.

2. Preoperative complications.

3. Anaesthetic agents.

4. Anaesthetic techniques.

5. Blood loss.

6. Postoperative complications.

A five-year survey was made of 604 operations at the Hospital for Sick Children, Toronto. They consisted of 219 cases of cleft lips from 1955 to 1959, and 385 cases of cleft palates from 1956 to 1960 . There were no deaths in this series.

A previous report by Dr. C. I. Junkin ${ }^{1}$ stated that from 1924 to 1952,1250 cleft lips and 1300 cleft palates, or a total of 2550 patients, received surgical treatment. From 1935 to 1952 six surgical deaths occurred-four cleft lips and two cleft palates.

The potential problems facing the anaesthetist from admission to discharge of the patient are discussed. The techniques presently used in the conduct of anaesthesia are described.

\section{Classification}

It is helpful for the anaesthetist to have a knowledge of a classification of these lesions since they are related to many of the problems. Although embryological classifications exist, the anatomical ${ }^{2}$ seems more suitable. This classification is as follows:

1. Isolated cleft lip

2. Cleft lip and cleft palate

(a) Unilateral or bilateral

(b) Complete or incomplete

(c) Any combination of $(a)$ and $(b)$

3. Isolated cleft palate

\section{INCIDENCE AND OCCURRENCE}

These deformities, considered together, constitute the third most common congenital anomaly, exceeded only by meningocele and club foot. A Canadian survey in 1959 reported an incidence of 1:930 live births ${ }^{3}$ for cleft lips and

${ }^{*}$ Departments of Anaesthesia, the Hospital for Sick Children, and University of Toronto, Toronto, Ontario.

Can. Anaes. Soc. J., vol. 10, no. 6, November, 1963 
palates. An analysis of laterality shows 43 per cent had left-sided involyement, 24 per cent had right-sided involvement, and 33 per cent had bilateral involvement., ${ }^{4,5}$ Cleft lip, with or without cleft palate, is more common in males, while the isolated cleft palate is more common in females.

Genetically, 33 per cent of lip deformities and 25 per cent of isolated palate deformities have a family history. The heredity factor is believed to be a Mendelian recessive character with nutritional deficiency in the first ten weeks of pregnancy a contributing factor. Associated congenital malformations occur in 14 per cent of cleft lips with or without cleft palate and in 33 per cent of isolated cleft palates.

\section{Associated Congenital Malfókmations}

Two groups of associated congenital malformations may complicate anaesthesia in these cases.

A group of localized anomalies occur in the maxillofacial area creating technical difficulties in performing endotracheal intubation. The most common in this group is the Pierre-Robin syndrome consisting of microglossia, micrognathia, and cleft palate. The Klippel-Feil syndrome presents a similar situation as these patients havė short, web necks, cervical spine abnormalities, and cleft palates, An absent first mandibular arch and bilateral hypoplasia of the mandible associated with cleft palate occurs less frequently but may make intubation impossible.

The other group is associated with the circulatory, digestive, or bone and joint systems. The congenital cardiac and great vessel lesions have particular significance to the anaesthetist. The cleft lip series reveals such anomalies in a total of 11.4 per cent of cases, 5.5 per cent of which were anaesthetic hazards. The palate series had deformities in 12 per cent of cases of which 7 per cent posed anaesthetic problems.

Patients with severe and multiple deformities die frequently in the first few weeks of life, thus explaining the apparent lower incidence of associated congenital malformations in our series. These cases did not survive long enough for corrective surgery to be performed. This is illustrated in the period 1955 to 1961 when 26 deaths occurred in the first few months of life caused by severe congenital deformities in which lips and palates were secondary and never reached surgery. This series included four cases of Pierre-Robin syndrome.

\section{Preoperattve Assessment}

Cheiloplasties are performed routinely at the Hospital for Sick Children when infants have reached the age of three months. This is "considered the age of election since the baby is in good condition by this time. It is important to have the parents accept the baby preoperatively because there will be residual deformities.

The optimal age for cleft palate repair is considered to be 15 to 18 months, since exposure is more adequate at this age and the operation is well tolerated: 


\section{Preoperative Complications}

The preoperative complications in the physical status of these patients are the result of the obvious deglutition problems during the early months. These are overcome by the use of special nipples, Breck feeders, gavage, and indwelling plastic catheters. In spite of these efforts, nasal regurgitation and aspirations add to the anaesthetic problems.

An assessment of the nine preoperative complications in patients with cleft lips shows 26 cases (11.8\%). It is significant that 8.6 per cent were upper respiratory infections (Table I).

TABLE I

PREOPERATIVE COMPLICATIONS

\begin{tabular}{|c|c|c|c|c|c|}
\hline & $\begin{array}{l}\text { No. of } \\
\text { cases }\end{array}$ & $\%$ & & $\begin{array}{l}\text { No. of } \\
\text { cases }\end{array}$ & \\
\hline $\begin{array}{l}\text { CLEFT LIPS ( } 219 \text { cases) } \\
\text { 1. Bronchitis } \\
\text { 2. Nasopharyngitis } \\
\text { 3. Pneumonia } \\
\text { 4. Otitis media } \\
\text { 5. Renal infection } \\
\text { 6. Gastroenteritis } \\
\text { 7. Dystrophy } \\
\text { 8. Prematurity } \\
\text { 9. Chicken pod }\end{array}$ & $\begin{array}{l}8 \\
7 \\
4 \\
2 \\
1 \\
1 \\
1 \\
1 \\
1\end{array}$ & $\begin{array}{ll}3 & 6 \\
3 & 2 \\
1 & 8 \\
0 & 9 \\
0 & 46 \\
0 & 46 \\
0 & 46 \\
0 & 46 \\
0 & 46\end{array}$ & $\begin{array}{l}\text { CLEFT PALATES ( } 385 \text { cases) } \\
\text { 1. Nasopharyngitis } \\
\text { 2. Preumonia } \\
\text { 3. Bronchitis } \\
\text { 4. Otitis media } \\
\text { 5. Dystrophy } \\
\text { 6. Gastroenteritis } \\
\text { 7. Laryngo-tracheo-bronchitis } \\
\text { 8. Chicken pox } \\
\text { 9. Chronic sinusitis } \\
\text { 10. Anaemia } \\
\text { 11. Bronchiolitis } \\
\text { Total }\end{array}$ & $\begin{array}{r}33 \\
15 \\
4 \\
3 \\
2 \\
1 \\
1 \\
1 \\
1 \\
1 \\
1 \\
63\end{array}$ & $\begin{array}{rl}8 & 56 \\
3 & 90 \\
1 & 02 \\
0 & 7 \delta \\
0 & 52 \\
0 & 26 \\
0 & 26 \\
0 & 26 \\
0 & 26 \\
0 & 26 \\
0 & 26 \\
16 & 36\end{array}$ \\
\hline
\end{tabular}

Analysis of the preoperative cleft palate complications shows 63 cases (16.36\%). The high incidence of upper respiratory infections (13.48\%) is also apparent in this series (Table I).

\section{Preoperatrve Criteria}

These have been discussed previously by many authors, ${ }^{5-9}$ The basic requirements have been clearly established.

The patient must be in good general condition. Normal weight is desirable although nutritional deficiencies make this difficult to achieve. The average weight in our lip series was $12.2 \mathrm{lb}$. and in the palate series $22.8 \mathrm{lb}$.

The haemoglobin must be above $10 \mathrm{gm} . \%$. The normal level for a 3-month child is $11 \mathrm{gm} . \%$ and for an 18-month child is $12.5 \mathrm{gm} . \%$. Surgery was performed on four lips and seven palates with haemoglobin levels between 9 and $10 \mathrm{gm}$. Although those undergoing lip surgery had no „untoward sequelae, those undergoing palate surgery had four postoperative complications: two upper respiratory infections, one gastroenteritis, and one soft palate breakdown.

The patient must be free from infection. Swallowing problems and mouth breathing predispose to chronic respiratory disease. It may be extremely difficult to differentiate between the frequent rhinorrhoea (nasal regurgitation) occurring in these cases and a mild rhinitis. Here, the decision to operate must 
depend on the temperature and the clinical evaluation of the nose, throat, and chest. If doubt exists, surgery is deferred. Cultures are taken from both nose and

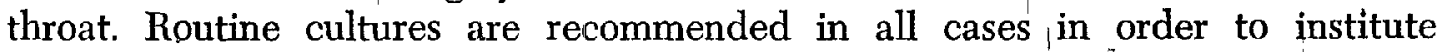
early antibiotic therapy when necessary. Many of these problems are avoided by careful screening in the admitting department with postponement for' several weeks if infection is present.

Norris and Saunders ${ }^{6}$ urge the admission of patients four days preoperatively for culture study to make sure infectious diseases are not incubating.

However, we favour immediate operation, if examination is normal, to prevent cross-infection. Roy et al, ${ }^{10}$ reporting 17,837 admissions to the Hospital for Sick Children in 1959, disclosed an over-all infection rate of 6.5 per cent, most of which seemed to be hospital-acquired. These authors have shown further that in a series ${ }_{8}$ of 203 patients with cleft lips and palates, 21.7 pen cent developed infection in hospital. The incidences were much lower among those who were kept in single cubicles or rooms than among those who were mixed with others in small rooms or those on open non-cubicled wards.

The otolaryngologists play a significant role in the preoperative control of these patients. Tonsillectomies are performed only when there is a definite indication. Operations prior to palate repair may interfere with tissue mobilization. On the other hand, an adenotonsillectomy performed postoperatively may damage $t$ united, tight palate and cause speech changes.

\section{SuRgical Repalr}

The cleft lip operation is that performed by Le Mesurier. ${ }^{12}$ The cleft palate? operation is usually a one-stage radical pushback procedure. ${ }^{5,12}$

\section{ANAESTHETIC Agents}

Many agents and techniques have been advocated for these procedures. ${ }^{j-9,14-22}$ Ethyl chloride and ether were used almost exclusively early in this series $(51.6 \%)$. Table II shows the transition in agents that has occurred for cheiloplasties during this five-year period. The intravenous relaxant combinations described by Dr. C. I. Junkin are shown. ${ }^{1}$ At the present time, we favour halothane, ether, and nitrous oxide, or halothane, ether, nitrous oxide, and succinylcholine with or without thiopentone.

Table II also illustrates the twelve combinations of agents used in the cleft palate series. Presently, thiopentone, succinylcholine, halothane, nitrous oxide, and ether are preferred when venepuncture is possible; otherwise, halothane, nitrous oxide, and ether.

\section{Anaesthetic TeChniques}

Table III shows that there were seven techniques used at the Hospital for Sick Children for the administration of these anaesthetic agents to cleft lip patients. Currently, the partial rebreathing-orotracheal-Ayre's technique is used in most cases. Only two of 219 cases were not intubated. These received 
TABLE II

Anaesthetic Agents

\begin{tabular}{|c|c|c|}
\hline & No. of cases & $\%$ \\
\hline \multicolumn{3}{|l|}{ CLEFT LIPS } \\
\hline 1. Ethyl chloride ether & 113 & 51.6 \\
\hline 2. Ethyl chloride-ether $-\mathrm{N}_{2} \mathrm{O}$ & 36 & 16.5 \\
\hline 3. Thiopentone-ethyl chloride-ether $-\mathrm{N}_{2} \mathrm{O}$ & 15 & 6.9 \\
\hline 4. Thiopentone- $\mathrm{C}_{10}$-succinylcholine-ether $-\mathrm{N}_{2} \mathrm{O}$ & 14 & 6.4 \\
\hline 5. Thiopentone- $\mathrm{C}_{10}$-ethyl chloride-ether & 9 & 4.1 \\
\hline 6. Thiopentone-succinylcholine-ether & 4 & 1.8 \\
\hline 7. Cyclopropane-ether & 1 & 0.46 \\
\hline 8. $\mathrm{N}_{2} \mathrm{O}$-ether & 1 & 0.46 \\
\hline 9. Ethyl chloride-ether-halothane & 8 & 3.61 \\
\hline 10. Thiopentone-succinylcholine- $\mathrm{C}_{10}$-halothane & 3 & 1.31 \\
\hline 11. Cyclopropane-halothane-ether & 1 & 0.46 \\
\hline 12. Thiopentone-succinylcholine-halothane-ether $-\mathrm{N}_{2} \mathrm{O}$ & 5 & 2.30 \\
\hline 13. Halothane-ether $-\mathrm{N}_{2} \mathrm{O}$ & 9 & 4.10 \\
\hline Total & 219 & 100 \\
\hline \multicolumn{3}{|l|}{ CLEFT PALATES } \\
\hline 1. Ethyl chloride-ether & 175 & 45.5 \\
\hline 2. Ethyl chloride-ether $-\mathrm{N}_{2} \mathrm{O}$ & 29 & 7.5 \\
\hline 3. Thiopentone-ethyl chloride-ether $-\mathrm{N}_{2} \mathrm{O}$ & 12 & 3.1 \\
\hline 4. Thiopentone-succinylcholine-ether $-\mathrm{N}_{2} \mathrm{O}$ & 36 & $9 . \overline{3}$ \\
\hline 5 . Thiopentone- $\mathrm{C}_{10}-$ ether $-\mathrm{N}_{2} \mathrm{O}$-ethyl chloride & 121 & 31 \\
\hline 6. Thiopentone- $\mathrm{C}_{10}$-succinylcholine-ether $-\mathrm{N}_{2} \mathrm{O}$ & 26 & 68 \\
\hline 7. Thiopentone-succinylcholine- $\mathrm{C}_{10}$-halothane- $\mathrm{N}_{2} \mathrm{O}$ & 4 & 1.0 \\
\hline 8. Ethyl chloride-ether-halothane & 26 & 6.8 \\
\hline 9. Cyclopropane-halothane-ether & 3 & 0.7 \\
\hline 10. Thiopentone-succinylcholine-halothane-ether- $\mathrm{N}_{2} \mathrm{O}$ & 39 & 10.2 \\
\hline 11. Halothane-ether-succinylcholine & 4 & 1.0 \\
\hline 12: Halothane-ether $-\mathrm{N}_{2} \mathrm{O}$ & 19 & 5.0 \\
\hline Total & 385 & 100 \\
\hline
\end{tabular}

TABLE III

Anaesthetic Techniques

\begin{tabular}{|c|c|c|}
\hline & 0. of cases & $\%$ \\
\hline $\begin{array}{l}\text { CLEFT LIPS } \\
\text { 1. Open-orotracheal-Ayres } \\
\text { 2. Intravenous-orotracheal-Ayres } \\
\text { 3. Intravenous-open-orotracheal-Ayres } \\
\text { 4. Partial rebreathing-orotracheal-Ayres } \\
\text { 5. Intravenous-partial rebreathing-orotracheal-Ayres } \\
\text { 6. Open-orotracheal-non-rebreathing } \\
\text { 7. Open-pharyngeal insufflation } \\
\text { (1) Recent tracheitis } \\
\text { (2) Recovering U.R.I. }\end{array}$ & $\begin{array}{r}154 \\
23 \\
21 \\
14 \\
3 \\
2 \\
2\end{array}$ & $\begin{array}{r}69.5 \\
10.6 \\
9.7 \\
6.8 \\
1.4 \\
0.9 \\
0.9\end{array}$ \\
\hline Total & 219 & 100 \\
\hline $\begin{array}{l}\text { CLEFT PALATES } \\
\text { 1. Open-nasotracheal-N.R. } \\
\text { 2. Intravenous-nasotracheal-N.R. } \\
\text { 3. Intravenous-nasotracheal-Ayres } \\
\text { 4. Open-nasotracheal-Ayres } \\
\text { 5. Intravenous-open-nasotracheal-Ayres } \\
\text { 6. Open-orotracheal-Ayres } \\
\text { 7. Partial rebreathing-nasotracheal-N.R. } \\
\text { 8. Partial rebreathing-intravenous-nasotracheal-Ayres } \\
\text { 9. Intravenous-open-nasotracheal-Ayres } \\
\text { 10. Partial rebreathing-nasotracheal-Ayres } \\
\text { 11. Partial rebreathing-intravenous-N.R. } \\
\text { 12. Open-pharyngeal insufflation }\end{array}$ & $\begin{array}{r}173 \\
67 \\
42 \\
33 \\
23 \\
11 \\
14 \\
s \quad 9 \\
3 \\
6 \\
6 \\
2 \\
2\end{array}$ & $\begin{array}{r}45.1 \\
17.3 \\
11.0 \\
8.5 \\
5.9 \\
2.9 \\
3.7 \\
2.3 \\
0.8 \\
1.5 \\
0.5 \\
0.5\end{array}$ \\
\hline Total & 385 & 100 \\
\hline
\end{tabular}


open-drop, pharyngeal insufflation anaesthesia because of recent tracheitis and recovering upper respiratory infection.

Table III shows also that an even greater variety of techniques-twelve, in number-was used in cleft palate surgery. At present, the intravenous, nasotracheal, and Ayre's technique is preferred in cases when venepuncture is possible. The partial rebreathing, nasotracheal Ayre's technique is used where venepuncture is not possible. Of the 383 patients intubated, 372 were done nasotracheally and 11 orotracheally. Although the orotracheal group was not ideal in the opinion of our surgical staff, it did prove reasonably acceptable.

\section{Practical Conduct of Anaesthesia}

\section{Monitoring}

On arrival in the operating room, all patients under $20 \mathrm{lb}$. in weight are placed on a hyperthermic blanket. Temperatures are recorded throughout the procedure using the rectal lead from an electric thermometer. Although problems in temperature control have been described, ${ }^{21,23}$ normothermia has been maintained satisfactorily in this manner throughout these series. Precordial stethoscopes enable the anaesthetist to follow cardiac rate and breath sounds. Blood pressure-cuffs of appropriate size are used. ${ }^{24}$ Visual monitoring of the respiratory pattern is accomplished by direct observation of the patient's chest and the anaesthetic bag in the manner to be described subsequently.

\section{Indiction}

For inhalational induction, an M.I.E. apparatus is attached to an Airmed grachine equipped with Fluotec vaporizer. Anaesthesia is commenced with $/ 2$ per cent halothane and 100 per cent oxygen. The halothane percentage is reduced gradually to 0.5 per cent, the ether concentration is increased, and the gas Hlows are adjusted to 50 per cent nitrous oxide and 50 per cent oxygen. This is adequate for endotracheal intubation. In the Ayre's T-piece system, $\mathrm{CO}_{2}$ elimination is assured by using a fresh gas inflow of at least twice the minute volume..$^{25}$ Although cleft lip patients require minimal flows of two litres and cleft palate patients four litres, higher flows are commonly used; airway pressures measured using this system have been found to be minimal.

When the intravenous route is used, thiopentone (2.5\%) $2 \mathrm{mg}$. per $\mathrm{lb}$. and succinylcholine $1 \mathrm{mg}$. per $2-3 \mathrm{lb}$. are the doses given.

\section{Intubation}

(a) Route of Intubation for Cleft Palates

There is a controversy regarding the ideal route for endotracheal intubation in cleft palate patients. Although our surgical staft considers that the nasotracheal approach provides superior exposure, many fentres favour orotracheal anaesthesia. The main criticisms of the nasotracheal route have been distortion of the operative field, inadequate size of the airway, and the introduction of infection. ${ }^{6,9}$

Distortion at the operative site has not been a problem in our cases. A 4.5 or $5.0 \mathrm{~mm}$. nasotracheal tube does provide an adequate-sized airway. 
However, the introduction of infection has been our chief concern. It is difficult to differentiate the common nasal regurgitations from low-grade rhinitis. The postoperative respiratory morbidity associated with nasotracheal intubation in this series (21.6\%) suggests that the orotracheal route should be considered. However, as pointed out by Roy, ${ }^{10}$ many of these infections were probably hospital-acquired.

The orotracheal exposure is improved by using special mouth gags such as the Doughty modification of the Boyle-Davis, ${ }^{27}$ the Roman tubular mouth blade as designed to fit the Crow-Davis mouth gag, ${ }^{28}$ or the new Sorensen mouth blade.

\section{(b) Tube Selection}

Table IV illustrates that intubation problems occurred in 3.7 per cent of our cleft lip cases and 7.8 per cent of our cleft palate cases.

Studies have been made regarding the selection of the proper size and length of tube to avoid kinking, accidental extubation, and endobronchial intubation." In our series, 3.5 and $4.0 \mathrm{~mm}$. Portex Magill tubes have been selected for lips and 4.5 and $5.0 \mathrm{~mm}$. for palates.

TABLE IV

Intubation Problems

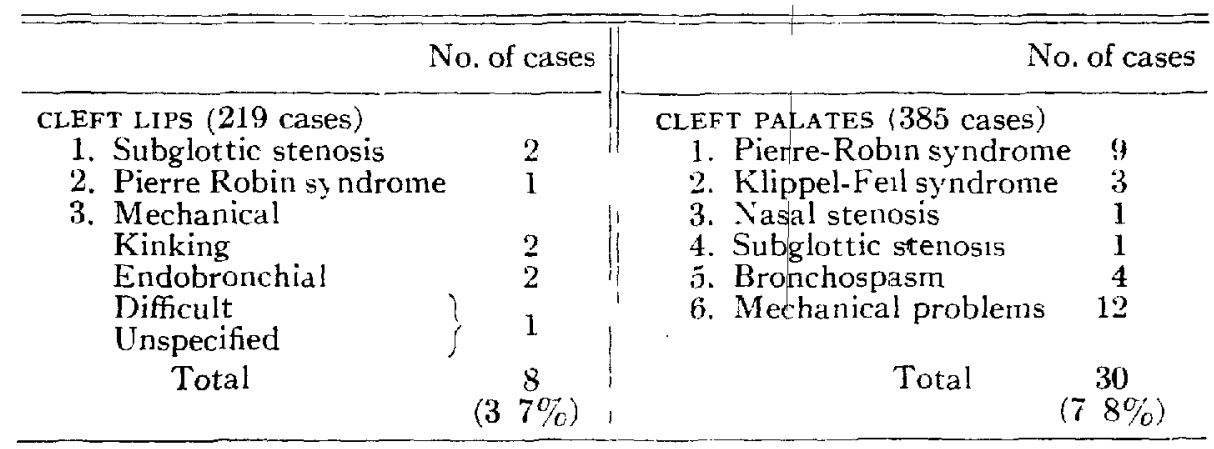

TABLE $Y$

\begin{tabular}{|c|c|c|}
\hline & $\begin{array}{c}\text { Internal } \\
\text { diameter } \\
\text { (nmm.) }\end{array}$ & $\begin{array}{l}\text { Length } \\
(\mathrm{cm} .)\end{array}$ \\
\hline 1. Lips & $\begin{array}{ll}3 & 0 \\
3 & 5 \\
4 & 0\end{array}$ & $\begin{array}{ll}11 & 0 \\
11 & 5 \\
12 & 5\end{array}$ \\
\hline 2. Palates & $\begin{array}{ll}4 & 0 \\
4 & 5 \\
5 & 0\end{array}$ & $\begin{array}{ll}14 & 5 \\
15 & 0 \\
16 & 0\end{array}$ \\
\hline
\end{tabular}

Cole tubes have been suggested for cleft lips-a 16 French replacing the $3.5 \mathrm{~mm}$. and an 18 French replacing the $4.0 \mathrm{~mm}$. Portex tubes. Accidental endobronchial intubation and accidental extubation on extension of the head, because of tube rigidity, are hazards. 


\section{(c) Technical Difficulties}

Orotracheal intubation in the cleft lip series presents féw problems. However, the anaesthetist may have difficulties because of the anatomical features of this age group-viz. a more cephalad and anterior position of the larynx, a more infantile shape and lie of the glottis, and a constriction at the cricoid ring.9 Intubation difficulties are minimized by the use of a head ring.

The nasotracheal intubation in cleft palates presents a difficult technical problem. The main obstacle is the tube impinging on the anterior commissure. The tube is directed anteriorly as it comes from the nose whereas the trachea leads posteriorly and downward. ${ }^{30}$ The simplest solution in approximating these angles is the use of a head ring Then the tube is introduced usually without difficulty.

In more difficult cases, the tip of the tube may be depressed- with Magill torceps with an assistant pushing gently on the tube. If flexion is inadequate, the assistant elevates the head slightly.

(d) Fixation of Tube

Surgical preparation-of the face often involves removal of the adhesive fixing the exdotracheal tube.

The orotracheal tube in the cleft lip series is fixed to the mid-point of the lower lip. This may be accomplished by silk sutures or using one of the new cellulbse water-resistant adhesives.

In the hips, the $\mathrm{Y}$ attachment of the M.I.E. set is firmly fastened to the endotracheal tube. One limb is fed by the tubing supplying anaesthetic gases. The other limb of this Ayre's type attachment has fastened to it two lengths of corrugated rubber tubing with a bag on the distal end with the tap removed. , This passes down over the chest of the patient and to the side where the anaesthetist is seated.

The cleft palate nasotracheal tubes are fixed similarly, directed cephalad over the head. The Ayre's type attachment is placed on the patient's forehead on a square of foam rubber. The unit is held in place by 1-inch adhesive tape encircling the forehead.

\section{Positioning}

Following intubation, the patient is positioned immediately on a head ring with as little movement as possible. Minimal movement at this stage is imperative to prevent tracheal irritation by the tube until the anaesthetic is stabilized. The surgeon requires that the head of the table be broken into slight extension. Extreme extension of the neck is to be avoided. The exaggerated Rose position has caused death from fracture of the odontoid process, obstruction of the vertebral veins, and cerebral venous congestion.

\section{Draping}

A metal bridge is placed over the patient's chest. An adjustables screw allows a horizontal plate to be angled close to the upper part of the chest. This provides excellent exposure both for the anaesthetist to his patient and for the surgeon to 'the operative field. McDonald points out that an increase in weight of $10 \mathrm{~kg}$., by 
leaning on the chest, doubles the respiratory work of an infant breathing spontaneously. ${ }^{31}$ Such a stand removes the drapes from the patients, safeguards the endotracheal attachments, and solves the problem of the "tired intern."

Intravenous stands are placed on the anaesthetist's side of the table to form a tent for the observation of the patient. The stand nearest the head carries the suction bottle for blood measurement. The shortest possible length of tubing passes from the bottle to the patient.

With this type of control, the patient is monitored throughout the procedure. Temperature control and blood loss are observed. The respiratory pattern is followed by observing the exposed bag. Assistance or control is accomplished easily when necessary. Patients are maintained on nitrous oxide, 0.5 per cent fluothane, and light ether.

\section{Blood Loss}

Numerous studies have been made of blood loss' during cleft lip and cleft palate surgery. ${ }^{32-36}$ These consider the percentage blood volume lost, techniques of measurement, and the methods of control. The methods described to control haemorrhage have been direct pressure (chalazion clamp for cleft lips), hypotensive anaesthesia, hypothermia, and local infiltration with epinephrine and local anaesthetic solution.

At the Hospital for Sick Children, procaine-epinephrine infiltration has been considered the method of choice for many years. It has replaced the routine use of cut-downs in cleft lip and cleft palate patients to replace the large blood losses. In lips $2-4$ c.c. of a $1: 150,000$ mixture is used. In palates, 10-12 c.c. is used with injections at six sites-the free edge, the lateral side, and the mucoperiosteal flap on each side. The use of epinephrine in the presence of halothane is controversial. Subcutaneous administration in small doses, as above, in carefully monitored patients, is reasonably safe, as shown by Jordan. ${ }^{11}$ Clinically, we have seen no problems with this combination in these series although electrocardiography has not been done.

Blood loss estimations were carried out in both cleft lip and cleft palate patients using this method of control. Table VI shows our results. The loss was measured

TABLE VI

BLOOD LOSS

\begin{tabular}{|c|c|c|}
\hline & Cleft lips* & Cleft palates $\dagger$ \\
\hline Average age, months & 38 & 225 \\
\hline Average weight, pounds & 122 & 228 \\
\hline Estimated average blood volume, c.c. & 490 & 912 \\
\hline Measured average blood loss, c c. & 154 & 472 \\
\hline Per cent of estimated blood volume & 31 & 51 \\
\hline \multicolumn{3}{|l|}{ RANGES } \\
\hline Age & 5 days to 8 months & 6 months to 48 months \\
\hline $\begin{array}{l}\text { Weight } \\
\% \text { Blood volume }\end{array}$ & $\begin{array}{c}7 \mathrm{lb} .5 \mathrm{oz} \text {. to } 19 \text { lb. } 9 \mathrm{oz} . \\
1-10\end{array}$ & $\begin{array}{c}12 \mathrm{lb} \text { to } 37 \mathrm{lb} . \\
1-14\end{array}$ \\
\hline
\end{tabular}

*112 cases $(12 / 3 / 59-20 / 3 / 61)$.

+179 cases $(4 / 4 / 59-12 / 1 / 62)$. 
volumetrically in suction bottles placed as close as possible to the head of the patient. Sponges were weighed gravimetrically on a dietetic scale.

Such blood losses are well tolerated. Early in this series several cleft palate patients who lost over 10 per cent blood volume were transfused. Since the above studies were completed transfusions have been a rarity.

\section{Postoperative Care}

Patients are placed immediately in a lateral head-down position at the conclusion of the operation. At this time it is imperative to aspirate secretions from the mouth and nasal passages meticulously. If this is not done there is danger of upper respiratory complications resulting in increased postoperative morbidity. Extubation is performed at the end of inspiration just before the patient is coughing or bucking on the tube.

A metal bridge or Logan's bow is placed across the upper lip to protect the operative site. If resuscitation becomes necessary this may be removed and later replaced.

The maintenance of an adequate airway is difficult at times. This is explained by postoperative oozing and the anatomical confinement of the tongue to a smaller space. The situation is controlled usually by a suture holding the tongue forward or a nasopharyngeal airway. It is important to select an airway with the bevel directed medially as the lateral bevel is obstructed easily against the pharyngeal wall. The patency is confirmed by listening through a bell stethoscope placed over the external opening of the tube. Marked airway problems such as severe Pierre-Robin or Klippel-Feil syndromes are nursed in a special micrognathia frame. This is an adjustable apparatus which holds the patient in a prone cerebellar position, assuring excellent drainage.

The patient is returned to the recovery room and placed in a croupette róutinely. Frequent suctioning by nasal catheter removes secretions and blood. If tracheitis develops, an observation period of six hours is considered essential. Patients may then be returned to the ward but problem patients remain in the recovery room as long as necessary. Decadron ${ }^{\circledR}, 4 \mathrm{mg}$. for patients under one year and $8 \mathrm{mg}$. for older children, is a useful adjunct in the therapy of postoperativę laryngeal oedema.

\section{Postoperative MoRbidity}

Types of complications with an incidểnce varying from 5 to 40.5 per cent have been reviewed by previous authors. ${ }^{18,21,23,43,44}$

Table VII shows the postoperative morbidity rates in our two series. The respiratory complications predominate. Two tracheotomies were performed in each group for tracheitis. It may have some significance that the orotracheally intubated lips show approximately half the complication rate of the nasotracheally intubated palates. Although we have not humidified our anaesthetic gases, the introduction of a system to maintain vaporization at $20-25 \mathrm{mg}$. per litre might be helpful in these cases. ${ }^{42}$ 
TABLE VII

Postoperative Complications

\begin{tabular}{|c|c|c|c|c|c|}
\hline & No. of cases & $\sigma_{0}$ & & No. of cases & $\%$ \\
\hline $\begin{array}{l}\text { CLEFT LIPS ( } 219 \text { cases) } \\
\text { 1. Upper respiratory }\end{array}$ & & & $\begin{array}{l}\text { CLEFT PALATIS ( } 385 \text { cases) } \\
\text { 1. Upper respirator }\end{array}$ & & \\
\hline infection & 8 & 36 & infection & 59 & 153 \\
\hline 2. Tracheitis & \pm & 18 & 2. Otitis media & 10 & \\
\hline 3. Otitis medid & 3 & 14 & 3. Pneumgnia & 8 & 23 \\
\hline 3. Pneumonia & 3 & $1+$ & 4. Tracheitis & 6 & 14 \\
\hline 4. Infected operative ste & 5 & 23 & 5. Gastroenterit1s & 4 & 1.0 \\
\hline 6. Gastroenteritis & 3 & 14 & 6. Tachycardia, anaennld, & & \\
\hline 7. Apnoea & 1 & 05 & epistaxis (one each) & 3 & 0.8 \\
\hline Total & $2 i$ & 124 & Total & 90 & 234 \\
\hline
\end{tabular}

\section{Postoperative Mortality}

Davies and Danks ${ }^{\top}$ emphasize that a mortality rate of 0.5 per cent is not acceptable. Musgrave and Bremner ${ }^{23}$ hiave presented an excellent review of mortality rates in cleft palate surgery. These rates vary from 3.8 per cent to nil. The present study of 604 cases at the Hospital for Sick Children has shown no mortality.

\section{Discussron}

The preoperative problems associated with cleft lip and cleft palate surgery result from the deformities themselves and the associated congenital malformations.

The lip and palate deformities may cause nutritional difficulties resulting in dystrophy or aspiration resulting in upper respiratory infections. Although the nutritional s̀tatus should conform to certain stated requirements prior to surgery, it may be necessary occasionally to correct the deformity to overcome the failureto-thrive syndrome. The high incidence of upper respiratory infections demands exacting assessment in both the admitting and preoperative examinations.

The associated congenital malformations create further difficulties in the technical control of anaesthesia. Serious circulatory, neurological, digestive, and bone and joint lesions add to these hazards .

The operative phase demands a smooth induction. When this stage is characterized by coughing, bucking, and cyanosis, complications invariably follow, both during the operation and in the postoperative period. Emphasis must be placed, on an operating arrangement by which the anaesthetist has excellent observation and control of his patient. The use of procaine-epinephrine infiltration has controlled the serious blood losses formerly associated with these procedures. Adequate humidification of anaesthetic gases would be helpful in reducing respiratory complications.

During the postoperative phase, management of the airway is the main problem. This has been controlled by pharyngeal tubes, tongue suturing, and a special micrognathia frame whenever indicated. The routine use of croupettes in the recovery room is valuable in this type of surgery. 


\section{SUMMARY}

Six hundred and four cases of cleft lips and cleft palates operated on oyer a five-year period at the Hospital for Sick Children, Toronto, have been reviewed. These cašes have been investigated under the headings: associated congenital malformations, preoperative morbidity, and postoperative complications. The conduct of anaesthesia for cleft lips and cleft palates used at the present time at the Hospital for Sick Children has been outlined.

\section{RÉSUMÉ}

Nous avons passé en revue 604 cas de fissures labiales et de fissures palatines opérées au cours de cinq |années au "Hospital for Sick Children", de Toronto. Nous avons recherché, chez ces malades, les malformations congénitaleş associées, la pathologie préopératoire et les complications postopératoires. Nous avons exposé la technique de l'anesthésie utilisée dans notre hôpital pour ces opérations.

Les problèmes préopératoires posés par la chirurgie des fissures labiales et des fissures palatines découlent des difformités elles-mêmes et des malformations congénitales associées.

Les difformités des lèvres et du palais peuvent amener des troubles de nutrition suivis de dystrophie, ou des aspirations suivies d'infections des voies respiratoires supérieures. Bien que l'état de nutrition devrait correspondre à un certain standard avant l'opération, on peut être forcé occasinnellement de corriger la difformité pour combattre le syndrome de défaut de développement. L'incidence élevée d'infections des voies respiratoires supérieures commande une grande atțention dans les examen\$ d'adminission et dans les examens préopératoires.

Les malformations congénitales associées amènent d'autres difficultés dans le' contrôle de l'anesthésie. De sérieuses lésions circulatoires, neurologiques, digestives, osseuses et articulaires augmentent encore le risque.

L'induction doit être douce. La toux, le spasme et la cyanose, à ce stade, sont généralement suivis de complications durant et après l'opération. Il faut insister pour 'que, durant l'opération, l'anesthésiste puisse observer et contrôler parfaitement son malade. Les infiltrations de procaïne-éphédrine ont considérablement diminué les pertes de sang jadis și importantes au cours de ces interventions. Une humidification suffisante des gaz anesthésiques diminuerait les complications respiratoires.

Durant la phase postopératorre, tout le problème consiste à maintenir libres les voies respiratoires. Nous y sommes parvenus en utilisant des tubes nasopharyngés, en pratiquant la suture de la langue, et en utilisant, au besoin, un rétracteur spécial pour petites mâchoires. L'usage courant de “croupettes" à la salle de réveil est utile pour ce genre de chirurgie.

\section{REFERENCES}

1. Junkin, C. I. Andesthesia for Harelip and Cleft Palate Repair. Proc. Canad. Anaesth Soc., $30-33$ (1952).

2. Davis, J. S. \& Rrtchie, H. P. Classification of Congenital Clefts of the Lip and Palate TA.M.A. 79: 1323 (1922). 
3. Congenital Abnormalities Reported on Physician's Notice of Birth Form. Prov. of Ontario, Dept. of Health, courtesy A. H. Sellers, Director, Division of Medical Statistics.

4. Five Year Report, 1955-1959, Cleft Lip and Cleft Palate Research and Treatment Centre, Hospital for Sick Children, Toronto, Canada.

5. Lindsay, W. K. Cleft Palate. In Benson, C. D.; Mustard, W. T.; Ravitch, M. M.; SNYDER, W. H. Jr.; \& Welch, K. J. Paediatric Surgery, Vol. 1, Chap. 10. Chicago: Year Book Medical Publishers (1962).

6. Norris, W. \& Saunders, B. C. O. Anaesthesia for Repair of the Cleft Lip and Palate, Brit. J. Anaesth. 27:597 (1955).

7. Davies, R. \& Danks, S. Anaesthetic Care in Cleft Lip and Palate Surgery. Anaesthesia 8: 275 (1953).

8. Smith, R. M. 'Anaesthesia for Infants and Children, pp. 258-262. St. Louis: C. V. Mosby (1959).

9. Ennis, G. E. \& Sherman, D. A. General Anaesthesia. In Holdsworth, W. G. Cleft Lip and Palate, 2nd ed, chap. 8. London: W. Heinemann (1957).

10. Roy, T. E. et al. A Survey of Hospital Infection in a Paediatric Hospital. Canad. M.A.J. 87: 531, 592, 656 (1962).

11. Whaley, J. B. The Otolaryngologists' Role in the Care of the Cleft Palate Patient. J. Canad. Dent. Assoc. 23: 574 (1957).

12. LeMesuruer, A. B. Hare-lips and Their Treatment. Baltimore: Williams \& Wilkins (1962).

13. Veau, V. Divisions Palatine. Paris: Mason \& Cie (1931).

14. Ayre, P. Anaesthesia for Hare-Lip and Cleft Palate. Brit. J. Surg. 25: 131 (1937).

15. - - Endotrachial Anaesthesia for Hare-Lip and Cleft Palate in Babies. Anesth. \& Analg. 16: 330 (19:37).

16. Slocum, H. C. \& Allen, C. R. Orotracheal Anaesthesia|for Cheiloplasty. Anesthesiology 6: 355 ( 1945).

17. Daplyn, P. Vinethene Anaesthesia for Repair of Hare-lip and Cleft Palate. Brit. Med. J. 2: $117(1946)$.

18. Mahaffey, J. E.; Sprouse, J. H.; Witherspoon, S. M.; \& Oxner, G. Anaesthesia for Cleft Lip and Cleft Palate Surgery. J. Plast. \& Reconst. Surg. 26: 596 (1960).

19. Chevalier-Thewissen, C. Anaesthesia for Hare-Lip and Cleft Palate in Infants and Young Children. Acta Anaesth. Belg. 11: 25 (1960).

20. Leigh, M. D. \& Kester, H. A. Endotrachial Anesthesja for Operations on Cleft Lip and Palate. Anesthesiology 9: 32 (1948).

21. Salamrtre, E. \& Rackow, H. Changing Trends in Ahesthetic Management of Child with Cleft Lip-Palate Malformations. Anesthesiology 23: 610 (1962).

22. Taylor, C. \& Stoelting, V. K. A Modified Ayre's T. Tube Technic-Anaesthesia for Cleft Lip and Palate Surgery. Anesth. \& Analg. 42: 55 (1963).

23. Musgrove, R. H. \& Bremner, J. C. Complications of Cleft Palate Surgery. J. Plast. \& Reconst. Surg. 26: 180 (1960).

24. Moss, A. J. \& Adams, F. H. Problems of Blood Pressure in Childhood. Springfield, Ill.: C. C. Thomas (1962).

25. ONCHI, Y. et al. Studies on the Ayre T-Piece Technique. Far East J. Anesth. 1: 30 (1957).

26. Collins, V. J.; Bromner, B.; \& Rovenstine, E. A. Anesth. \& Analg. 40: 392 (1961).

27. Doughty, A. \& London, M. B. A Modification of the Tongue-Plate of the Boyle-Davis Gag. Lancet i: 1074 (1957).

28. Barton, R. T. \& Roman, D. A. Endotracheal Technique for Adenotonsillectomy. Arch. of Oto-Laryngol. 241 (1955).

29. Eckenhoff, J. E. Some Anatomical Considerations of the Infant Larynx Influencing Endotracheal Anesthesia. Anesthesiology 12: 401 (1951).

30. Gillespie, N. A. Endotracheal Anaesthesia, 2nd ed., p. 108. Madison: University of Wisconsin Press (1948).

31. McDonald, I. H. Infant Physiology \& Anaesthesia. Brit. J.'Anaesth. $32: 22$ (1960).

32. Dingman, R. O.; Ricker, O. L.; \& IoB, V. Blood Loss in Infant Cleft Lip and Cleft Palate Surgery. J. Plast. \& Reconst. Surg. 4: 333 (1949).

33. Berger, J. C.; Harnis, H.; \& Slaughter, W. B. A Clinical Method for Estimating Blood Loss \& Transfusion Requirements in Infants. J. Plast. \& Reconst. Surg. 21: 315 (1956).

34. Kilduff, C. J.; Wyant, G. M.; \& Dale, R. H. Anaesthesia for Repair of Cleft Lip and Cleft Palate using Moderate Hypothermia. Canad. Anaesth. Soc. J. 3: 102 (1956). 
35. Tempest, M. N. Some Observations on Blood Loss in Hare-Lip and Cleft Palate Surgery. Brit. J. Plast. Surg. 11: 34 ( 1958).

36. Gondon-Jones, R. G. The Reduction of Bleeding in Hare-Lip and Cleft Palate Surgery. Brit. J. Anaesth. 34: 481 (1962).

37. Junkins, C. I.; Smrri, C.; \& Conin, A. Fluothane for Paediatric Anaesthesia. Canad. Anaesth. Soc. J. 4: 259 (1957).

38. Miller, R. A., Gilbert, R. G., \& Brindule, G. F. Ventricular Tachycardia during Halothane Anaesthesia. Anaesthesia 13: 164 (1958).

39. Rogoman, E. P., Johnston, A. E.; \& Conn, A. W. The Use of Epinephrine during Halothane Anesthesia with Respect to Ventricular Irritability in Dogs. Anesth. \& Analg. 42. 109 (1963).

40. Johnstone, M. \& Niseet, H. I. A. Ventricular Arrhythmia during Halothane Anaesthesia: Brit. J. Anaesth. 33: 9 (1961).

41. Jomdan, W. S. Effect of Epinephrine during Halothane Anesthesia in Man. Anesthesiology 23: 152 (1962).

42. Chase, H., Trotra, R.; \& KIr'mone, M. Simple Methods for Humidifying Nonrebreathing Gas Systems. Anesth. \& Analg. 41: 249 (1962).

43. Gainsfond, J. C., Hanna, D. C; \& Monhem, L. Endotracheal Anaesthesia Complications Associated with Head and Neck Surgery. J. Plast. \& Reconst. Surg. 24: 463 (1959).

44. Mastens, F.; Hansen, J.; \& Robinson, D. Anaesthetic Complications in Plaśtic Surgery. Plastic \& Reconstructive Surgery $24 ; 472$ (1959). 